\title{
INNOVATIVE ECONOMY IN THE LIGHT OF REFORMS AND BUSSSINESS MODERNIZATION ${ }^{1}$
}

\author{
Petar Đukić \\ University of Belgrade, Faculty of Technology and Metallurgy, Belgrade, Serbia
}

date of paper receipt:

03.05.2018.

Review article date of sending to review:

05.05.2018. date of review receipt:

16.05.2018.

\section{SUMMARY}

It is widely obvious that the modern business depends on many new previously unknown factors: innovations, technology expanding, information dispersion and collection, culture, imaginations, and other intangible productive factors. This paper deals with some of the unexpected changes that we could recognise as the most influential ones in the new economy era. Purpose and findings of the substantial theoretic and empirical analysis are oriented to the modernisation and sophistication of today business, especially in developing, emerging and small countries. All of them are exposed to severe market reforms, in order to be more efficient and effective in global and regional level. This paper contains the analysis of content of global development documents and literary materials, as well as cross-referencing of statistical and other available data. The findings of this study could result in better orientation of industrial policies and clearer path for the future broader researches to be conducted in this field.

Keywords: invention, innovative economy, modern business, modernisation, sophistication, sustainable business

\section{INTRODUCTION: TERMINOLOGY DISCTINCTION AND OBJECTIVES}

Numerous analysts, not only economists, but also sociologists, philosophers, engineers, have noted that since the end of XX century, there have constantly been essentially different developments in the socio-economic structure of today's world. The effect of innovations and the rapid pace of continuous changes are the primary reason for the absence of a unified, single theoretical distinction of the terms "new economy" and "new society". Previously, such occurrence was identified by sociologists Alain Touraine and Daniel Bell as "post-industrial society". Some others used the category "information society", whereas Peter Drucker created the term "knowledge society" or "post-capitalist society". It is obvious that fairly heterogeneous, uncertain and somewhat elusive processes involving not only the economy and technology, but the lifestyles and cultures around the world, could not have been encompassed by a single, well suited term. Judging by the current situation, such status will be maintained for some time.

In the response to the question of why there are no unified theoretical postulates on "new society"

\footnotetext{
${ }^{1}$ The paper has been prepared within the project"Modelling of the development and integration of Serbia into world trends in the light of economic, social and political commotions", reg.no. 179038, financed by the The Ministry of Education, Science and Technological Development of the Republic of Serbia
} 
and "new economy", the reason should be sought in the pace of change or in the effect of innovation. Innovation (as derived from Latin "innovātiōn" - something new or different introduced) is "the process of transitioning a new idea into practical application". It is preceded by invention, as "the process of transforming intellectual ideas into a new artefact (usually being a product or a process)" (Stošić 2013, p.2). While this interpretation may appear as somewhat confusing, most people realize that innovation cannot be achieved without new and different ideas, as well as without its conceptualization, and ultimately, without respective application that mainly depends on the practical needs of the people. One should not forget that all of the above is conditioned by the endless variety of needs, as well as their continuous generation and innovation, due to changes in technologies, culture and lifestyle in general.

Innovative economy primarily involves the economic structure and economic processes that are mostly based on innovation. However, the notion of an innovative economy did not occur simply as a result of the impact analysis of the innovations themselves. Even before the use of this concept there was a shift in the focus of the analysis of economic development from the effects of labour, capital, technology and natural resources into new so-called immaterial or intangible factors such as knowledge, information, culture..., which was, alongside with the notions of management and entrepreneurship, and in the absence of a better term, named the new economy.

The new economy is a term that explains the qualitative redefinition of the structure of productive factors, undergoing change in the late XX and early XXI century. As such, it encompasses the meaning of the comprehensive impact of all tangible and intangible factors that condition economic activity and development as a whole, with particular reference to categories such as productivity, efficiency, sustainability, etc.

\section{NEW ECONOMY AND REDEFINITION OF PRODUCTION FACTORS}

Every systemic and paradigmatic ${ }^{2}$ economy was once "new". That was also the case more than ten thousand years ago in the changes caused by the agricultural revolution (Beeby, Brennan, 2008, p. 268). Similar changes have been made by the expansion of international trade that came through the merchant capitalism of the XV and XVI century. Then came the original industrial era (XVIII and XIX century), followed by the phase of new industrial revolutions (XX century), and finally, the famous globalization era. The authors who reviewed them and defined their principles made no epochal discoveries. They only managed to register changes that spread diligently thanks to advancements in technology, communications and culture. One thing is certain - innovations have become an integral part of all the crucial socio-economic changes in people's lives during the 20th century. However, the XXI century brought about the expedition of these innovations and even more drastic changes

\section{THE THEORETICAL EVALUATION OF THE “NEW ECONOMY”}

The creator of modern economy Adam Smith although indirectly, insisted on innovation as the driving force of positive change and development in general, alongside with many other authors. Smith in "The Wealth of Nations" claims that freedom of business and market choice, international division of labour, specialization, as well as the competition of entities with equal rights in the market, leads to the development and efficiency of each economy. Therefore, Smith wrote two and a half centuries ago, stated in a prophetical manner that there is a "natural course of things", according to which "a major portion of the capital from a growing society is focused onto agriculture, followed by manufacture and finally onto foreign trade" with the prospect that such a change in the structure would have to reverse the order of things in all modern European countries (Smith 1970, p. 537).

${ }^{2}$ Paradigm is the word from the ancient Greek, meaning an example. It was used by Thomas S. Kuhn in his work "Structure of Scientific Revolutions" (1962) to show that the dominant thinking system and the method of thinking change due to changes made through respectable scientific models and achievements - examples (Kuhn, 1980). 
The Marxist interpretation of the social effect of the technological changes of the XIX century industrial capitalism through the phrase "development of productive forces" accented the emerging contradiction between technology and people. Technological progress towards this development model leads to the minimization of the role of "living labour" in comparison to the "materialised one" or technological one, which further produces labour surplus, generates the "reserve army of labour" and increases unemployment. No one is as disillusioned any more on the matter that automation and robotics lead to the reduction of directly employed labour, and that it is one of the risks of a technological civilization (Vinay, Nandy, 2012).

The entire spectrum of new terms and concepts referred to the ever-lesser economic and developmental impact of the sector usually named industries, that is, of the manufacturing industry. When information and ideas, strategies and decision-making systems became more influential on market results than the number of products achieved within the specific time unit and when the material product as the objective of economic activity increasingly started to be replaced by the vast array of services, the aforementioned Bell skilfully used the category "post-industrial". Under the influence of modern, progressive and increasingly digitalized technologies, the term "digital economy" was introduced later. In the effort to accentuate certain aspects of the new economy, the terms "weightless economy" and the "knowledge-based economy" have emerged, as the determinants that en masse may somehow fit into the rather vague but comprehensive term "new economy".

\section{INNOVATION - A LUCRATIVE COMMODITY OR STRATEGIC ADVANTAGE: AN EXAMPLE OF ASIA}

Knowledge has become a key factor that has spawned many innovations as well as new technological solutions by systematic expansion following the Second World War. First of all, economist James Tobin confirmed that in the 1970s, the contribution of knowledge to growth and productivity in advanced economies was over $70 \%$, whereas the contribution of labour and capital was only $12 \%$. In Japan, even at such early stage, the contribution of knowledge was as much as $95 \%$, with all the other factors being only 5\%. This brought forth many other structural changes. Due to labour productivity growth in the "new knowledge-based industry", the number of production staff in the OECD countries was abruptly cut down from about $2 / 3$ of the total employees during the sixties, to just around 1/3 at the end of the XX century. (Filipović, Đukić, 2007; Đukić, Đukanović, 2014). Whenever the discussion on the role of economic development and the long-term relative growth of national economies or regions is initiated, we are always faced with a paradigmatic example of Japan, which emerged as a Phoenix from the ashes of the Second World War and evolved until the 1990s utilising its innovation strategy and knowledge to create and implement new technologies. Somewhat later, Drucker ${ }^{3}$ explained what the category "social entrepreneurship" meant for the entire Japan, and that Japan, during the 1990s, implemented overly traditional and conservative policy of restructuring and industry, which included too many employees. Ichimura explained in a comprehensive way that a wide range of factors, from depopulation and aging of the population, to poor administrative organization and industrial policy, caused the later trailing of Japan, as the opposite to it being noted as the prime example of global growth in the XX century (Ichimura 2016, pp. 70, 71).

Either way, in the course of the last decades of the XX century, it was necessary to adapt to the entrepreneurial growth model, which became the key advantage for creating a multitude of new jobs, thus becoming a haven of the workforce in the restructuring processes. From the United States, through the Czech Republic, to Turkey and Indonesia, thanks to the entrepreneurial economy, the reform of the real sector of the economy and rapid technological change were easier and more

\footnotetext{
${ }^{3}$ In generating the idea of „the new society“ Drucker referred to the evolution of the term "scientific management" he attributed to the economist Fritz Machlup and to the founder of scientific management theory Frederick Winslow Taylor
} 
successful (Drucker 1993, p. 119).

OECD analyses have shown that the innovation economy has enormous potential in synergy with entrepreneurship, and not only in the so-called sector of high and advanced technologies, but particularly in medium and lower technologies. Namely, the notion of "new technology" changed very quickly. There is a danger that many changes in the knowledge-based economy are attributed exclusively to information and communication technologies. French author F. Rischard convincingly demonstrated that "the new world economy" implies a "radically different business system" that has nothing to do with the Internet or with a "narrow concept of a new economy," and that it brings "a new method of thinking that was brought by the economic and technological revolution” (Rischard, 2008, p. 19).

The aforementioned developmental fatigue of Japan which occurred in 1990s was luckily followed by China's expansion, which is likely to be joined by some other countries in the future that are probably to be positioned at the top as the new growth champions. The Asian financial crisis of 1977 only briefly spread to the whole world. Its consequences did not greatly counterbalance the whole of Asia, which also avoided the major devastating effects of the global crisis of 2008-2009, which hit the European continent in several waves. Growth in the leading Asian economies of China and India has remained dynamic and has supported many smaller Asian economies. The secret of Asian ascension, occurring at the end of the XX and the beginning of the XXI century, is undoubtedly related to the global initiative and development of international trade, as well as to the principle of innovation that is nurtured not only in the most technologically advanced economies. This is testified to by a illustrated OECD report referring to innovative Asia. The economic scene of the 1970's and 1980's launched the so-called small Asian tigers such as Singapore, Taiwan, Hong Kong ... Dynamic growth based on knowledge and innovations brought South Korea into focus, only for China to follow, with the limelight being rapidly turned towards India, Vietnam, Indonesia... Asian examples of "innovative intensive economies" and knowledge-based new economies are not the only ones but they are very indicative as they give a chance to less developed economies of other continents.

\section{KNOWLEDGE, INNOVATION AND INCOME GROWTH}

Recent economic research on generating long-term growth particularly underlines the category of technological changes, resulting in the "endogenous technological change theory". This theory aims to "reveal the method by which private market forces, decisions in public policy and alternative institutions lead to different patterns of technological change." Such direction of growth theory, in contrast to neoclassical theory, is primarily focused on the changes themselves and benefits from them. For the purpose of the authenticity of the message, we shall deviate from the regular practice and quote the following paragraph in its entirety: "Technological change - which increases output produced for a given bundle of inputs - is a crucial ingredient in the growth of nations. The new growth theory seeks to uncover the processes which generate technological change "(Samuelson, Nordhouse 2009, pp. 567)

However, any technological change is a product that is susceptible to severe market uncertainties and frequent failures as technology is a public good that is expensive to produce but suitable for reproduction. Consequently, Governments increasingly seek to provide strong intellectual property rights for those who develop new technologies (Samuelson, Nordhouse 2009, p. 568). The basic feature of technologies as the best possible combination of science, skills, creations and crafts is that it is mostly a public asset, as it can be simultaneously used by a large number of market participants, thus contributing to rapid expansion of their utilization and increase of the overall social impact. Without the notion to diminish this effect and with the intention to support private interest in scientific discoveries and technological innovations, governments seek to protect developers of technological changes by protecting the so-called intellectual property. Intellectual 
property (embodied through legal institutes in the form of inventions, patents, licenses ...) is one of the most important features of a modern market economy that guarantee long-term growth. The World Economic Forum (WEF) places the quality of the institutions as the main or the first of the twelve "pillars of competitiveness" of national economies. The conclusion that a long-term growth requires a proper combination of knowledge in its broadest sense, innovation and institutional arrangements that provide support and protection, remains indisputable.

The role of knowledge legitimately emerged in recent theory and practice of "total factor productivity" (TPF - Tobin, Carillo, 2005). Bearing in mind the growth of its economic and technological importance, Peter Drucker was the first to name a very formidable social group formed on the fundamentals of competencies as "knowledge workers" (Drucker 1995, p. 23). Unlike regular workers, they classify as different group, and as bearers of the economy and the knowledge society they seek employment in the modern services sector, not exclusively in high technology sector.

The latest global practices show that economic activity is no longer divided into a capital-intensive and labour-intensive one. Nowadays, it seems that we need to consider "knowledge-intensive" activity as a dedicated aggregate economic sector. In doing so, all sub-sectors of the knowledge economy have essential preconditions for success, although this does not mean that they will automatically succeed (OECD 2014). Differences in the income of countries such as Mexico, Brazil, South Korea during the 1960s were negligible, but in the late 20th century Korea already made 9 USD per working hour, in Mexico and Brazil hourly wage was not more than 2 USD, whereas in China it amounted to only 0.6 USD (Đukić, 2013, p.68). In the meantime, China has become the world's leading economy based on a comparable overall GDP (calculated on purchasing power parity - GDP p.p.p.), while the average hourly earnings of Chinese workers nowadays amount to about 2.65 USD.4

According to per capita income, China is still a medium-developed country, meaning that we could classify its relative innovation results and development into the context of some of the mediumsized economies of the Western Balkans. To illustrate the comparison, data for Japan and Poland will also be tabulated, according to the Global Competitiveness Index (GCI) report.

Based on the information from the World Economic Forum, China with a 8113 USD per capita income is placed above Montenegro (6628 USD per capita) and Serbia (5376.3 USD per capita), but below Croatia (12095 USD per capita). Of all the selected countries (relevant for our analysis) in Table 1, Japan has the highest general competitiveness rank (column 1), which occupies the 9th place on the world rankings. However, its ranking among the world's nations is even more favourable when it comes to pillars within the third block, pillars: 11th business sophistication (column 3); and 12th innovation (column 4). In order to perceive the entire picture, we have used Technology readiness levels (column 2). The average of the global index of these three pillars (ranks from columns 2-4) is given in column (5). The synthetic rank obtained by this method can be conditionally named synthetic innovativeness. We used it to compare these derived relative estimates with respect to the overall ranking of the given countries.

The results obtained indicate that the average rank coefficient of a country, with respect to the field of business sophistication and innovation as opposed to the general ranking of the country may be either lower or higher than 1 . If it is higher than 1, in our case it means that the economy in question is an innovative intensive economy, whereas the values below 1 indicate a net lower inclination towards innovation and sophistication (modernization) of businesses.

In all of the cases regarding the post-transition countries or in the countries undergoing reforms (such as the former socialist economies of the Balkans, as well as Poland and China), this coefficient is significantly lower than 1 . The only exception is Slovenia, which was the most developed constituent republic of SFR Yugoslavia, having started its individual development in 1991, becoming a member of the EU in as early as 2004. The Slovenian innovation and modernization coefficient amounts

\footnotetext{
${ }^{4}$ Author's calculation per official data on income and exchange rate of Chinese Yuan (https://www.statista.com/ statistics/233886/minimum-wage-per-hour-in-china-by-city-and-province/, accessed on 25 May 2018)
} 
to 1.26 , whereas in the case of Japan, this coefficient is clearly the highest and amounts to 1.63. In spite of the delay in growth elaborated above, in recent decades Japan has maintained its position as an innovative and technologically intensive economy, in line with its long tradition of being technologically developed and modernized (Table 1). The table also contains values of comparable income (GDP per capita - column 6). For clearer understanding, the Figure 1 which complements the table will, by means of graphic representation of these values, provide comparison by using income of Poland as the benchmark value - unit income measure $(=1)$.

Table 1 Comparative structure of competitiveness ranking of certain countries, with the business sophistication and innovation coefficient, compared to the income

\begin{tabular}{|c|r|r|r|r|r|r|r|}
\hline & $\begin{array}{c}\text { (1) Gen. } \\
\text { rank } \\
2017\end{array}$ & $\begin{array}{c}\text { (2) Rank } \\
\text { Techno } \\
\text { readiness }\end{array}$ & $\begin{array}{c}\text { (3) Business } \\
\text { sophistication } \\
\text { rank }\end{array}$ & $\begin{array}{c}\text { (4) } \\
\text { Innovation } \\
\text { rank }\end{array}$ & $\begin{array}{c}(5) \\
\text { Average } \\
(2,3,4)\end{array}$ & $\begin{array}{c}\text { (6) } 1 / \\
\text { Average } \\
(2,3,4)\end{array}$ & $\begin{array}{c}\text { Income per } \\
\text { cap. }\end{array}$ \\
\hline Croatia & 74 & 72 & 82 & 106 & 94 & 0.78 & 12095.2 \\
\hline Serbia & 78 & 48 & 110 & 95 & 102.5 & 0.82 & 5376.3 \\
\hline Montenegro & 77 & 69 & 101 & 91 & 96 & 0.84 & 6628.6 \\
\hline BiH & 103 & 81 & 115 & 123 & 119 & 0.86 & 4308.2 \\
\hline Albania & 75 & 35 & 74 & 87 & 80.5 & 0.93 & 4203.4 \\
\hline Slovenia & 48 & 47 & 41 & 35 & 38 & 1.26 & 21320 \\
\hline Poland & 39 & 73 & 57 & 59 & 58 & 0.66 & 12350 \\
\hline China & 28 & 15 & 33 & 28 & 30.5 & 0.91 & 8113 \\
\hline Japan & 9 & 15 & 3 & 8 & 5.5 & 1.63 & 38717.3 \\
\hline
\end{tabular}

Source: GCI Reports (WEF) for 2017/2018 and author's calculations

In addition to the income of each country, instead of general ranking, the respective ascending grade (from 1-7) of competitiveness according to selected competitiveness pillars (WEF) was used. The average grade for the 9th pillar - techno readiness; 10th pillar - business sophistication and 12th pillar - innovation, was provisionally named an assessment of innovation-technological performances (from 3.6 - $\mathrm{BiH}$ to 6.8 - Japan).

Coefficients of the average grades thus obtained that were aptly named as the "innovationtechnological performance" (ITP); and Global Competitiveness Index (GCI) differ slightly in relation to the parameters in Table 1 and only in the case of Slovenia they reach 1, in the case of Japan 1.03 and in all other cases they range between 0.87 and 0.96. (Figure 1.)

The conclusion is as expected: the income brings about the innovation-technological performance of the economies. However, in the cases of their centrally planned political and economic heritage (the Balkan countries and Poland), this heritage leaves an impact on the somewhat weaker applicability of the achieved innovations, as well as to the poorer assessments of the existing "business sophistication" and "technological readiness". Again, Slovenia has, as the most developed country, distinguished itself as an example of how innovation can be used to improve general technological performance in a relatively short but sufficiently long period, but with a very stimulating institutional environment (EU membership for more than a decade). 
Figure 1 Illustration of the income conditionality of innovation-technological performances for the group of selected countries

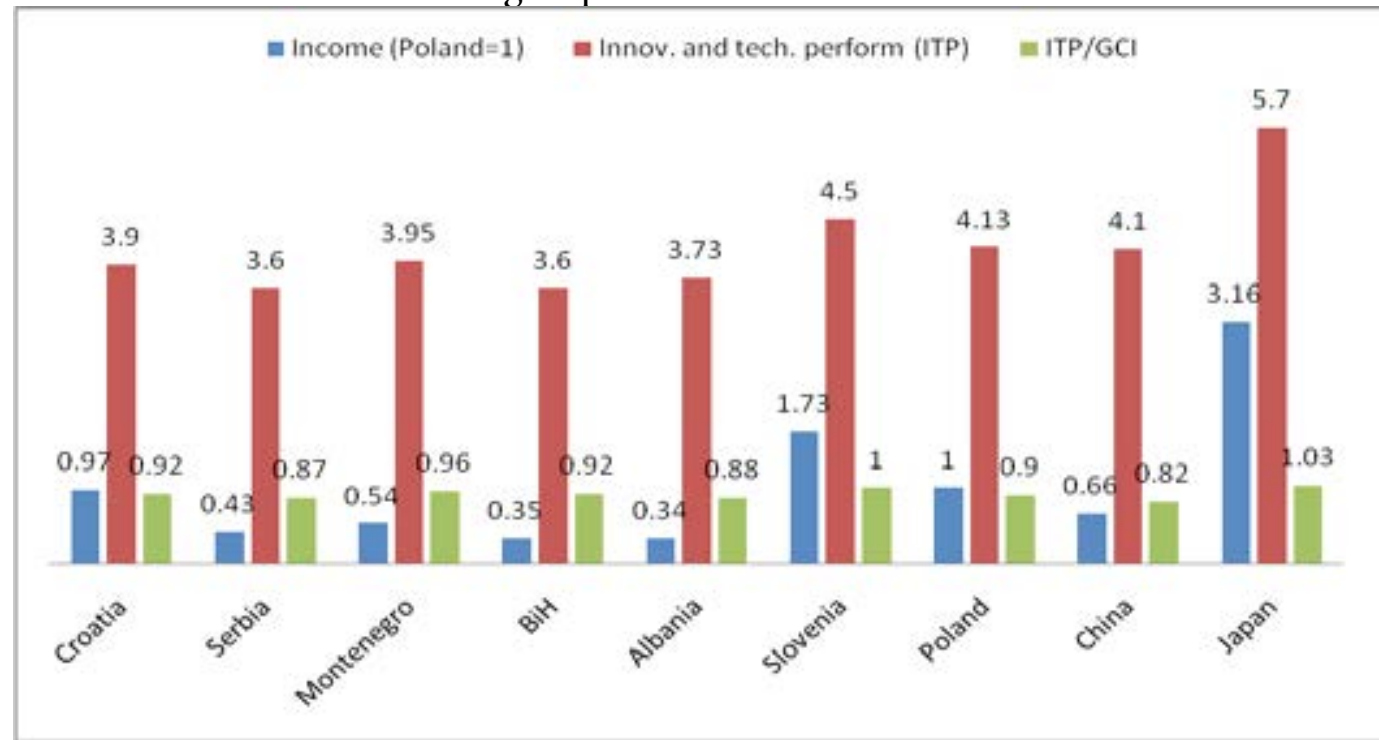

Source: GCI WEF 2017/2018, and author's calculations

The above finding almost completely fits into the qualitative assessments of the World Economic Forum and the OECD claiming in their own way that the benefits of applying new technologies and innovations do not spread fast enough in developing countries or in fast-growing big economies. Simply put, benefits from this sector in conditions present in the less developed countries with lower-income are relatively less compared to the conditions of long-term market development. For innovation and a knowledge-based economy, particular importance is attributed to the factor of institutions, according to which underdeveloped countries, recently established democracies and shallow-established reforms have been fairly poorly assessed.

\section{RISKS OF INNOVATIVE ECONOMY}

The development of technology, as well as of crafts and science, or put simply integration of useful knowledge and skills with scientific research, has brought new potential, but also enormous and terrible threats. They were particularly elaborated by Aldous Huxley (Brave New World, 1932), who in his vision of reproductive technology and "learning in a dream," drew attention to a vast dystopia of a knowledge-based economy (Huxley, 2009). He came to the conclusion that this could lead to the creation of a "new society" in which "a man is nothing and the system is everything". Sometime later, such concept was repeated by Alberto Mussolini in his fascist military-political concept by saying that "man is nothing and the state is everything" (Đukić 2014, pp. 28, 29). The totalitarianism of knowledge and technology remains a real threat and the subject of research not only of social psychology or culture, but also of human or social economy, as well as of industrial economy or labour economy.

\section{RISKS OF ADAPTATION TO TECHNOLOGICAL CHANGES}

Technological changes have generated another risk. It is the pace that people can hardly adjust to. In 1972, Alvin Toffler pointed out the possibility of a revolutionary transition from an industrial to a "super-industrial society" that would bring "too rapid changes at too short intervals", whereas those changes would shock people unable to manage within them. Toffler's hypothesis is something that is already happening today, particularly in the perception of digital actions that cannot be sufficiently acquired by the older generations, which in some ways increases the difference in costs 
and quality of life and the intergenerational gap. (Đukić 2014, p. 30)

Finally, today's findings on the increase of the risk of being inept to rapid technological changes are also found in the latest reports on global competitiveness of the World Economic Forum (WEF 2017/2018). Thus, in the introductory part of the Report, it is explicitly stated that today's technological changes are spreading so rapidly that their consequences are unpredictable, and the adjustment is becoming increasingly difficult and risky. According to the report, technological innovations have become an integral part of the practice of less developed and fast-growing economies, but they are not sufficiently rapidly commercialized in their current economic environment. Moreover, there is a great risk of losing jobs, as well as social stratification and an increase in inequality on this basis. (Schwab, Sala-i-Martín - ed., 2017, p. 12)

\section{INCOME DIFFERENCES AND QUALITY OF GROWTH}

Increasing the differences among the people both in terms of income and wealth is a process that can not be attributed exclusively to the innovative economy, but is closely related with all aspects of the new economy. It is natural that at a higher income level increases the income differences represented graphically as the well-known "bulge" of Lorenz's curve. However, the Lorenz curve is today increasingly distorted in almost every country of the world. Inequalities are increasing, among other things, as a result of innovation, technological exchange and expansion of international trade, which applies for nearly the entire world. The process of differentiation started very strongly, especially in the last decade of the XX century. Figure 2 graphically depicts comparable inequalities measured by the Gini coefficient, which occurred between 1990 and 2000. Inequalities in average income per individual country were slowly decreasing, with the main beneficiaries of such trend being China and India. However, the inequalities within national communities maintain constant increase, even in the situation where the GDP growth rate has been significantly reduced during the XXI century in most of the economies shown.

Figure 2 Increase of inequality in countries undergoing market reforms as well as in OECD economies

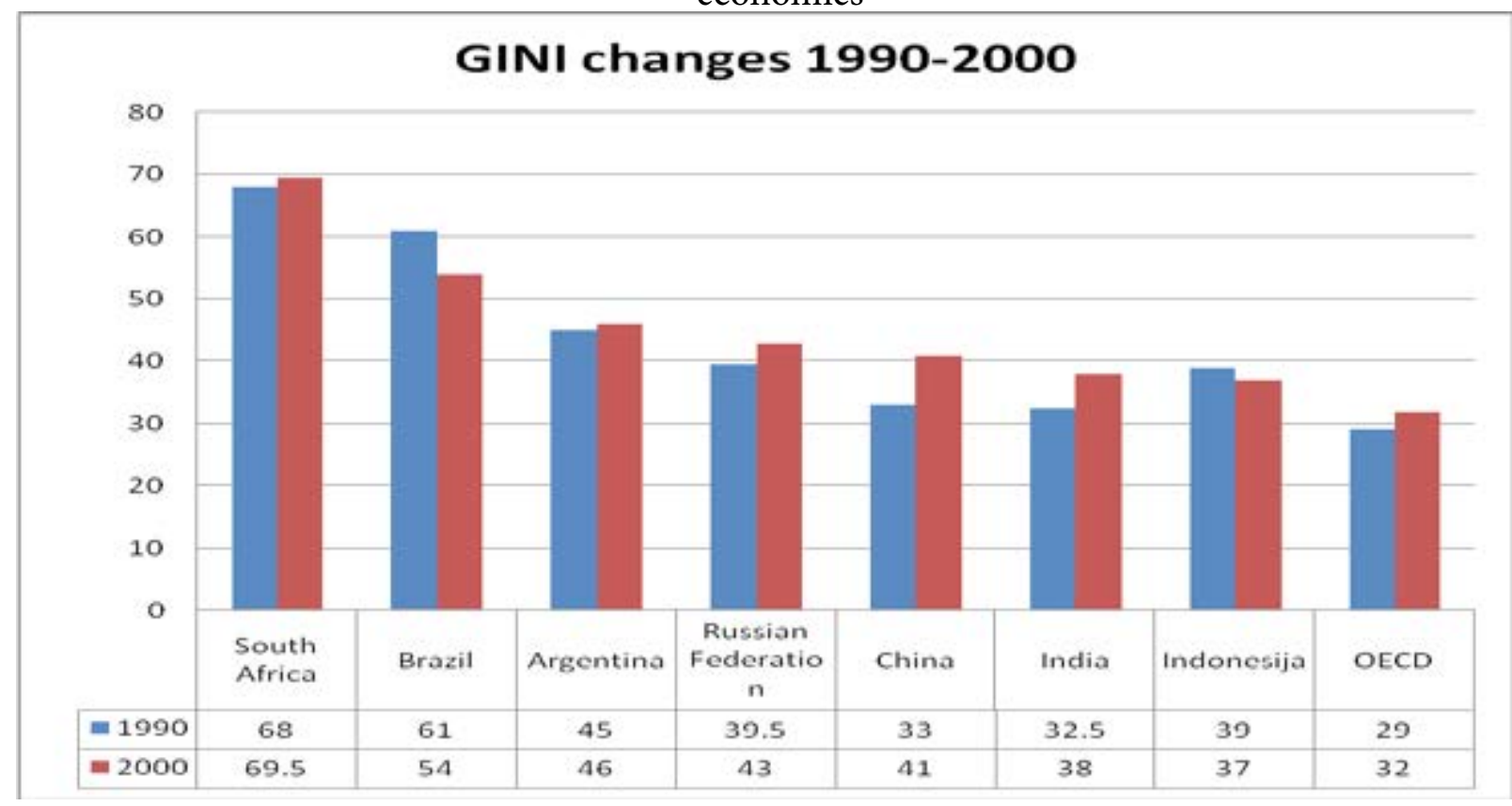

Source. OECD 2014

Inequality researchers throughout the world have found that nowadays for an individual to be accomplished on any plan, $80 \%$ depends on the economic strength and potential of the country 
he was born in, whereas only $20 \%$ depends on his personal abilities. Branko Milanović called such occurrence the residential rent (Milanović 2016, p. 230). In all cases, except in Brazil and Indonesia, income differences and inequalities have been drastically increased. The continuation of such a scenario was guaranteed for the entire period in the XXI to this day, except for the brief episodic decline at the time of the global recession 2009-2012.

\section{INNOVATION AS A COMMODITY OR ENTREPRENEURSHIP POTENTIAL}

\section{ENTREPRENEURSHIP AND INNOVATION}

The Austro-American economist Jozef Schumpeter is often mentioned in the literature as the pioneer of the innovation theory. In his work "Capitalism, Socialism and Democracy" from 1942, he convincingly and graphically discussed about innovation as a critical and crucial dimension of economic change. He also defined the entrepreneur as the carrier and the most important driver of innovation through the process of "creative destruction", which aims to create new values (Stošic 2013, pp. 1-3). Otherwise, the entrepreneurship theory was fundamentally established by Richard Cantillon who, in the 1930s very effectively demonstrated how the people take over initiative and create their own business/jobs on the market, by working for an unsecured salary (Cantillon, 1983, p. 56) Then the entrepreneurship theory was further very successfully developed by Jean-Baptiste Say in France, and particularly, promoted as the principle named "fourth factor of production" by Alfred Marshall (Marshall, 1987, pages 162,167 ..) only to finally have the works of Peter Drucker, through Schumpeter.

"Creative Destruction", which was first directly referred to by Schumpeter, was what Marx would have called a revolution of productive forces, and in the second half of the XX century it was referred to as scientific and technological revolutions. Is the 4th technological ICT-based revolution of today only one of stages of the latest technological revolution or a possible cardinal introduction to the new economy? What is the new economy in the first place, if not a product or a continuation of all the previous "new" economies?

\section{INNOVATION ECONOMICS AND DEVELOPING COUNTRIES}

There are vast opportunities and associating advantages of innovative economies and dedicated technology systems or system sectors in many of today's economies. These advantages are manifested not only in the field of high and advanced technologies, but also in many other sectors. Practice has shown that fish export from Uganda, wine export from Argentina and Chile, as well as medicinal herbs export from India was greatly improved through innovations and with the extensive use of knowledge (OECD 2014).

In addition, many opportunities are provided in the sector of lower technologies, as well as in improving the quality of exports. Such situation was exploited by Malaysia for the production of palm oil and various palm oil-based products. This is where we come to the field of application of knowledge-based economy in agriculture. Such innovations are extremely relevant from a social point of view, as well as from an environmental point of view, as they enhance the growth and quality of life. The World Economic Forum is a global expert-scientific organization that studies and ranks competitiveness globally. (OECD 2014, p. 230).

It clearly shows that research and development nowadays have a greater impact on poverty reduction in comparison to large public investment. Namely, public investments are by their very nature inefficient due to the lack of entrepreneurial initiative and innovation activities, given the fact that the motives of participation in them are mainly of redistributive nature (the struggle over the common loot represented by the size and scope of public funds).

It is evident that research and development has a greater impact on poverty reduction than large 
public investments. This finding by the OECD researchers speaks sufficiently of the fact that innovations are elusive, as they keep occurring and spreading in an unrestrictive environment. This also applies to local innovation as well as innovation of the informal sector. Apart from the standard notion that the informal sector, by definition, is harmful, OECD researchers in developing countries state that they contribute to social inclusion in this case by demonstrating a growing impact on inclusive development. There are even agencies that regulate copy or reproductive rights for music or certain books, as well as of domestic local-made items to promote tourism in Indonesia, the countries of Africa and Latin America (OECD, 2015, pp. 86). Even so, the innovations in the informal sector are inclusively essential for the innovation economy and policies of developing countries and fast-growing economies.

Figure 3 Comparative Indicators of Global Competitiveness Index (GCI) according to WEF $2017 / 2018$ which could define the perspectives of the innovative economy concept

\begin{tabular}{|c|c|c|c|c|c|c|c|c|}
\hline \multicolumn{9}{|l|}{140} \\
\hline \multicolumn{9}{|l|}{120} \\
\hline \multicolumn{9}{|l|}{100} \\
\hline 80 & & & & & & & & \\
\hline 60 & & I & & & & & & \\
\hline 40 & & & & & & & & \\
\hline 20 & & & & & & & & \\
\hline 0 & Serbia & ontenegro & $\mathrm{BiH}$ & Albania & Slovenia & Poland & China & Japan \\
\hline - General rank & 78 & 77 & 103 & 75 & 48 & 39 & 28 & 9 \\
\hline Wehnol. readiness (2) & 72 & 48 & 69 & 81 & 35 & 47 & 73 & 15 \\
\hline Business sophistication (3) & 110 & 101 & 115 & 74 & 41 & 57 & 33 & 3 \\
\hline - Inovations (4) & 95 & 91 & 123 & 87 & 35 & 59 & 28 & 8 \\
\hline
\end{tabular}

Source: WEF 2017/18

Based on the research of the target social challenges facing these countries and due to the rapid increase in inequalities and social differences, it is necessary that countries, peoples and individuals in the future focus on the social effects of innovation and knowledge through education policies and incentives for entrepreneurial innovations.

\section{INNOVATIVE ECONOMY, REFORMS AND INCLUSIVE DEVELOPMENT}

As for the reforms, most of them relate to the market and market structures. However, the assessment of reforms, as a rule, somewhat differs depending on whom they are made for. The US organisation Freedom House has, for its own purposes defined the reforms of general democratization, i.e. an indicator of a system of changes towards a new free (unrestricted) order. They are only partially useful for the purpose of this paper, but they should be mentioned nevertheless. Freedom House ranks the reform success rate by a score of 1 (for the most successful) to 7 (the weakest score). In a review of the status of all 29 economies in transition, the best rated are the (Baltic) countries in Northern Europe, Estonia being the most successful (1.93), whereas Uzbekistan has been awarded the lowest rank in 2017 (6.9). Interestingly, both paradigmatic countries were part of the former Soviet Union. Very good results of the reforms were achieved by most Central European countries, as well as Slovenia (from the former SFRY).

To summarize, countries of the Central Balkans, that is, the place of this event, in terms of promoting and developing democracy, were, as far as their overall transition process is concerned, assessed with average ratings ranging between 3 and 4. Only Bosnia and Herzegovina and Albania were rated lower, between 4 and 5. Namely, according to the ranking of the reform progress, Estonia 
is 1st, Slovenia 2nd, Croatia 11th, Serbia 12th. Montenegro 13th, Albania 14th. If the income per capita is calculated by purchasing power, then the indicators of economic development almost coincide with the ranks as provided in reforms (Figure 4).

Figure 4 Reform success score as per Freedom House for the group of selected transition countries

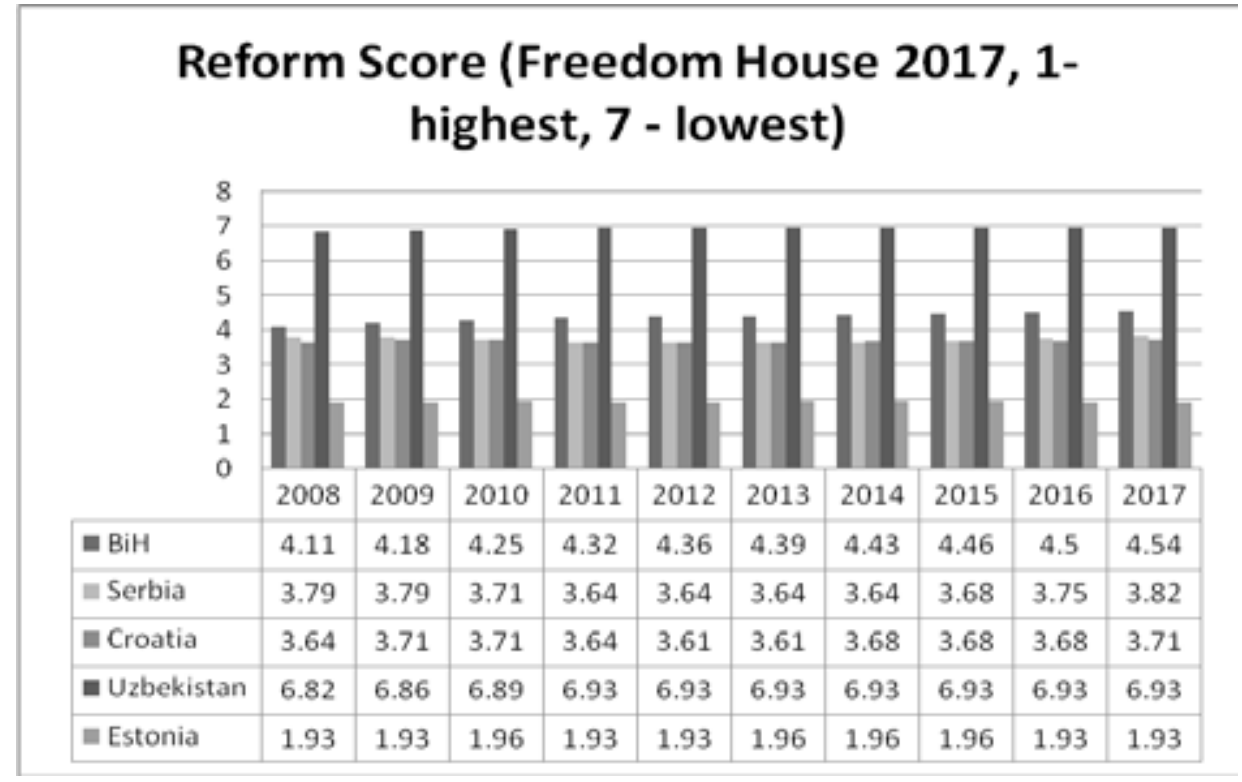

Source: https://freedomhouse.org/report-types/nations-transit

Not even the WEF has refrained itself from dealing with the quality of growth and redefining the sustainability of the competitive position the WEF established itself. Therefore, the report for 2017/2018 mentiones the indicators of inclusive growth or development, for the first time. Inclusion is a category that has entered economy from the field of social psychology, and involves engaging in social processes. Thus, inclusive development is the one that enables faster inclusion of as many people as possible in economic activity, education or socio-political activity. Inclusiveness is the barrier for exclusivity - exclusion, omission, discrimination, corruption and renting. Human development or development with a "human face" has somewhat longer institutional and theoretical evolution than the late assessment of WEF (Carillo, 2005, Jovanović, Gavrilović 2014, p. 23). Although this is only the beginning of a, by the looks of it, exhausting and difficult research work, it is necessary to support WEF researchers in an attempt to determine how much benefit the broadest layers of society have from growth in the long and short term. Previous results, applied to more than 100 countries show that in $43 \%$ of cases, growth in assessed national cases did not positively affect inclusive sustainability. On the other hand, it has been shown that countries that did not stand out in dynamic development and high income show a tendency towards inclusive growth, and vice versa, many highly developed countries fail in achieving sufficient level of inclusive development. The first group of countries with a higher inclination towards inclusiveness includes Cambodia, the Czech Republic, New Zealand, the Republic of Korea, and Vietnam, whereas the second is comprised of Brazil, Ireland, Japan, Mexico, Nigeria, South Africa, United States (Schwab, Sala-i-Martin, 2017)

Initially, this sufficiently indicates of the necessity for a different, more complex view of the comparative "competitiveness" of the nations in today' changing world. The "social inclusive development" itself becomes a kind of social innovation, which is precious for the development of the concept and the theory of sustainable development (Đukić, Đukanović 2015). 


\section{NEW ECONOMY: INNOVATION AND REFORMS OF TRANSITION COUNTRIES}

Following the fall of the Berlin Wall in Europe and the whole world, the term "transition" (transition from administratively regulated economies to the market economy, political pluralism and the rule of law) became popular and widely used. In order to avoid misunderstandings about whether it is a matter of a post-socialist or any other transition, this term is often added to the term "countries undergoing reform". However, in their broadest sense, reforms could also have been interpreted as the need for transformation, change of form and the essence of doing business. Of all the other keywords, expressions and categories at our gatherings, including this conference, why have the reforms been retained most of all? Reforms in their broadest sense are constantly present in the economic life of most of the world, due to technological innovations and cultural changes requiring the restructuring of the economy and society-state. After all, innovation is the biggest challenge for reforms. Nowadays, it is obvious that China, regardless of the monolithic "red" ideology and the official political-party monopoly, is the country undergoing radical reforms that stimulate entrepreneurship, innovation and a strong market initiative. Why is it that reforms really encourage innovation, and innovations cause reforms to be?

\section{FUNCTIONAL INNOVATIVE ECONOMY REACHING: RECOMMENDATIONS}

Due to the fact that innovative ideas and abilities are scattered across the world and that all they require to light up - is a spark. Secondly, the world is oriented towards innovations that know no borders, whether they may be ethnic, state, political, ideological, or even continental. If there had been no technological globalization, ever since the ancient times, the implementation of technical inventions and a series of discoveries and innovations would be of little use both in the past and today's world. In Serbia, as well as across the Balkans, we have examples of three key personalities (not only) of Serbian scientific and technological history: Nikola Tesla, Mihajlo Pupin and Milutin Milanković, which in a certain way act as an illustration of the phenomenon of multinational and globalized technological history (Figure 4). All three of them were ethnic Serbs, but were born in Austro-Hungary, acquiring knowledge and achieving scientific results across the capitals of Europe. Ultimately, the first two of them experienced the commercialization of their scientific results and their materialization through technical innovations and scientific institutions in the United States, whereas Milanković achieved success, but in Vienna.

Figure 4 Three of the greatest Serbian scientists and innovators: engineers Nikola Tesla, Mihajlo Pupin, and mathematician Milutin Milanković - all born in Austro-Hungary
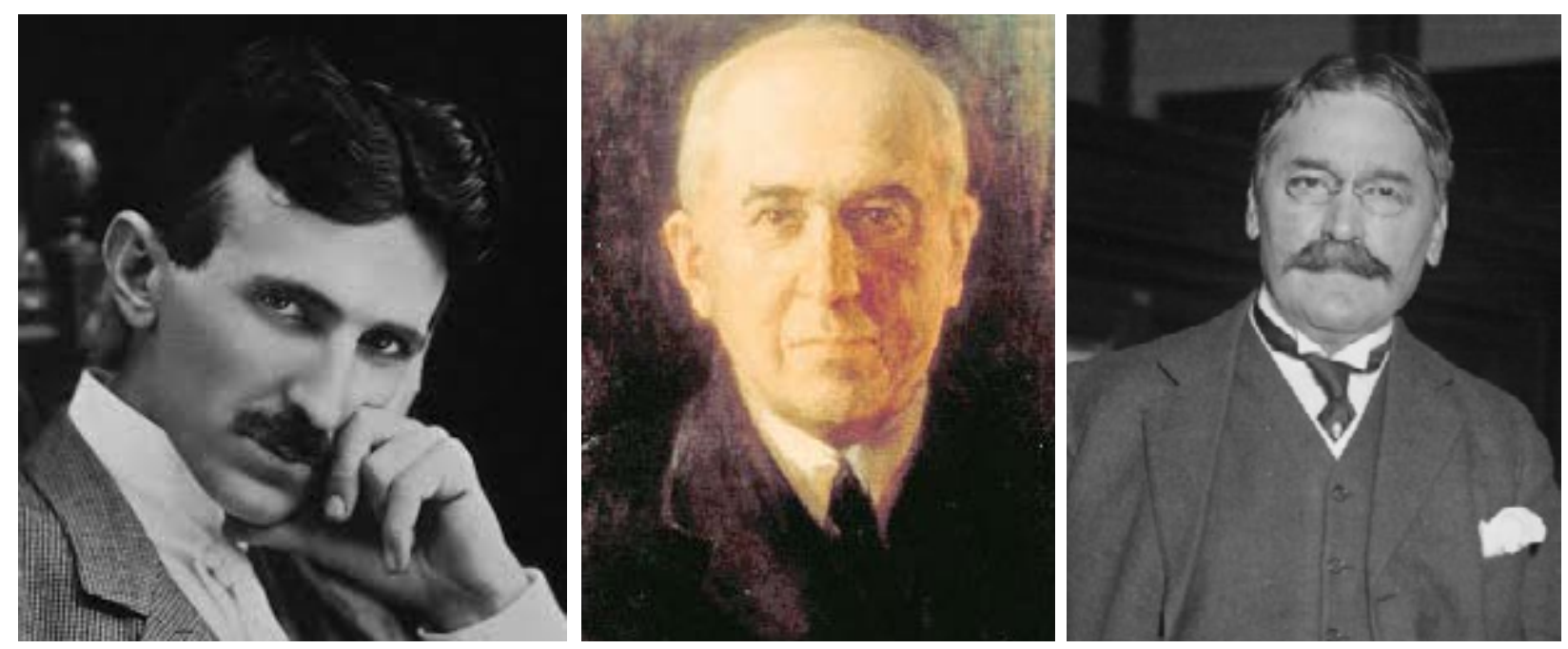

Picture sources: Wikipedia 
What is the point of the above? It is a matter of fact that the US began its rise to the top of global economies precisely through the entrepreneurial model of innovative economy. Probably the scientists from less developed countries will one day seek a place to verify their ideas in an Asian country, and then on other continents as well. The outflow of quality personnel from Serbia, as well as from the countries of the Central Balkans in general, is slowly shifting from western destinations to China. This is a natural consequence of uneven global development and for the purpose of balancing the process of "brain drain and brain gain" in the long run. It is necessary to provide strong and stable local institutions, an incentive international economic and political scene, as well as innovative industrial policy. The strategy of local and global climate action, as well as the policy of implementing the Paris Climate Agreement, despite (occasional obstructions and challenges) remains an area of great opportunities for such innovative joint projects (Klimenko, 2016)

\section{SOCIAL, HUMANISTIC AND ENVIRONMENTAL CONTENT OF COMPETITIVENESS}

It seemed that the prospect of global economic and technological progress had lost its soul, that is, until the outbreak of the global economic and financial crisis in 2008- 2012. Every progress was measured by the growth of global and national levels of GDP. It was as if no one was interested in the social and humanistic consequences of global economic and technological progress.

Today, ten years following the outbreak of the unexpected global economic crisis, many essential hidden facts and latent risks are coming to the forefront, both analytically and practically, even at the level of sustainability assessment and perspective of the global competitiveness index. The World Economic Forum still does not deviate from the 12-pillar model of competitiveness in the function of competitiveness indicators. However, competitiveness still includes the conditions to achieve growth in the long run. There are 12 of them. However, in its latest report, WEF says that at this moment it is important to divert attention to the wider social context of economic growth in the world, as well as to the human and environmental consequences and goals of economic progress. This is where certain indicators that tried to promote "green growth" or "green GDP " years ago in the EU, shyly come into play, precisely under the suspicion that GDP as an indicator partly hides the indicators and the impacts of economically unsustainable flows arising from the too intensive exploitation of natural resources, devastation and degradation of the ecosystem, the accumulation of greenhouse gases and the increase of social risks such as poverty, hunger, extreme inequalities, new diseases, and so on.

Innovative economics should in that sense be connected with the "green" or "circular" economy, for the purpose of a wider and complex issue of redefining the role of the "new economy" on a national and global scale. For example, one of the indicators of modernization of Green Innovation of technology is their purpose. Are technologies heading towards a peacetime direction, in the function of improving the lives of most people (social, cooperative and green innovation), or are they encouraging the challenges of warfare or "capturing the mind" of people (Czeslaw Milosz)? Do new technologies deserve the legality and legitimacy of sustainability, creation and humanism, or are they directed towards death, destruction through computer manipulations?

The situation is similar with innovations and technologies that bring health uncertainties and risks, and relate to extreme means of pleasure, animal fighting, new drugs or narcotics. The entire new technological content and innovations should be reassessed and transparently disassemble in theory, in order to qualify it as green, humane and socially acceptable on the one hand; or as "dirty", inhuman, destructive and socially suspicious (unacceptable) on the other hand, precisely for the sake of transparency of the type of those innovations and their economic utilisation. 


\section{CONCLUDING REMARKS AND RECCOMENDATIONS: INNOVATION CHALLENGES OF TODAY AND TOMORROW}

\section{GENERAL}

The expansion and unpredictability of technological change provide opportunities for unprecedented changes. They occur due to the application of the convergence of the digital, physical and biological-technical dimensions of the processes characterized by modern technologies, which is often vaguely defined as the fourth technological revolution. This compaction of technologies has enormous potential as a source of growth, but the future of the process itself is uncertain. The key challenge is to free up the potential of innovation for growth, as well as for social well-being, that is, for a society that needs to reform national and global economic life, increase income and lead to structural transformations.

Innovative and creative (new) economy nowadays could be found everywhere about, not only in area of high technologies. Small countries have to ask for their chances for very useful, predominantly small innovations in manufacturing, agriculture, the public and private services, and everywhere around, even in public government. Innovations can be successfully stimulated by bettering (inclusive) institutions, legal state, democracy, cultural and education policies.

Concept of knowledge-based economy considers stable economic and legal environment and strong and stable institutions. Modern innovations are desperately needed to face the future of climate changes and other substantial challenges of the human race. "Green" growth and sustainable development could be supported and innovative entrepreneurship concept and practice.

\section{REFORM AND POST-SOCIALISTIC ECONOMIES}

Reforms in post-socialist countries have yielded uneven results. Many issues and omissions occurred due to their conception and implementation. Freedom House mentions huge differences, as well as the fact that the less developed half of the countries in transition are yet to reach the real GDP level from the time before the fall of the Berlin Wall. Some Balkan countries belong to this group, originating from the former Yugoslavia, such as Serbia, Bosnia and Herzegovina, Croatia and Montenegro. For example, Serbia and Croatia have reduced their share in global GDP throughout the XXI century because the global economy's growth rate was higher than the average growth rate in these countries ${ }^{5}$.

This is a sufficient reason to achieve far more intense mutual knowledge-based and innovationbased collaborative projects focused on export promotion, security and environmental protection, i.e. regional sustainable development. Many examples show that positive cooperation in the fields of energy restructuring, utilisation of new renewable energy sources and energy efficiency is an excellent opportunity for collaboration between small and large economies - an example of innovative energy cooperation between Serbia and Russia (Джукич, Джуканович, 2016, p. 10-15) Many papers in recent years, as well as the texts published in this very journal, elaborated the urgent need for intensive regional cooperation of the countries of the Western Balkans, not only of the former SFRY, with a firmer economic innovation-based cooperation. This cooperation should primarily originate from the imposed needs, based on registered and increasingly frequent natural disasters, (particularly the flood wave of 2014 that hit Bosnia and Herzegovina, Serbia and Croatia, which we wrote about in the editorial of Volume 3 of this Journal (Đukić 2014). The regulation of common watersheds of the rivers Sava and Drina, the construction of joint flood and drought embankments, fire control and joint intentions in order to prevent and mitigate climate changes

\footnotetext{
${ }^{5}$ Thus, the average annual growth rate for the last two decades of 1996-2016 in the world was 2.9\%, in Serbia $2.7 \%$, in Croatia 2\%, in Montenegro 2.44\%. Simultaneously, the Chinese average growth rate was 9.2\% (Đukić, 2018, p. 42).
} 
could represent an enormous contribution to regional cooperation and sustainable development. Technological innovations, particularly those related to networked and smart systems in energy, transport, and ecosystem protection should be used on a regional level without pretensions of being "high." It would be very useful to explore the consequences and climate change strategies of the Western Balkans region, as the respective positive examples already exist (Vugdelić - Chief Ed. (2016).

Therefore, the effects of future technologies are fairly unknown, as well as the policies and challenges of current technologies that illustrate the magnitude of shifts. It should also be noted that significant operating losses are expected in the technological transformation, particularly in the service provision sector. The key challenge is the tempo of change and transfer of labour intensive into capital- and innovation-intensive activities. The structure of occupations and the possibilities of engaging in a new technological reality have not yet been sufficiently synchronized. Knowledge workers that Drucker convincingly talked about could be of great help in conducting such synchronization. The innovative economy has gained momentum. In the time of new technologies, creating values for consumers to a greater extent than actually recorded by national statistics is advancement. Technologies are spreading rapidly with frequent turning points, but the process occurs in accordance with the principles of adaptation, continuous learning and the increasing role of artificial intelligence. Innovation could further lead to a better general welfare. It only needs a chance to do so. 


\section{LITERATURE}

Beeby A., Brennan An-M., (2008), Osnovi ekologije (eng, Ecological pinciples and Environmental Issues), Clio, Belgrade

Cantillon R., (1983), Opća rasrava o prirodi trgovine (fra. Essai sur la Nature du Commerce in Général, eng. Essay on the Nature of Trade in general), Center for Cultural Activities, Zagreb

Carillo, M. R., (2005), Human Capital formation in the new Grawth theory: the Role of Social Factors http:/www.vww.tuwien.ac.at/hanappi/ageso/rp/carillo_2992_pdg (accessed on March 2011)

Drucker F. P., (1993), Inovacije i preduzetništvo (eng. Innovation and Enterpreneurship), Belgrade, Grmeč-Privredni pregled (eng. Economic Overview)

Drucker F. P., (1995), Postkapitalističko društvo (eng. Post-Capitalist Society), Grmeč Belgrade,

Đukić P.. (2018) "Kvalitet ekonomskog rasta i perspektive institucija u Srbiji" (eng. Quality of Economic Growth and Perspectives of Institutions in Serbia), paper presented at the Counselling of Scientific Society of Economists of Serbia, 22 December 2017, "Ekonomska politika Srbije u 2018. godini. Kvalitet institucija i ekonomski rast" (eng. Economic Policy of Serbia in 2018. Quality of its Institutions and Economic Growth) (rev.by A. Praščević), Scientific Society of Economists of Serbia and Faculty of Economics in Belgrade, (pp. 163-174),

Đukić P., (2014) „Knowledge - Based New Economy and Society: With Regards to the Sustainable Development Concept ", Economics, Bijeljina Republic of Srpska, Volume 2, June 2014, pp. 23-49

Đukić P., Đukanović S., (2015) Održivi razvoj - ekonomsko-ekološki izazovi (eng. Sustainable Development - Economic and Environmental Challenges), Faculty of Technology and Metallurgy, Belgrade University

Đukić, M. P., (2013) "Društvo i ekonomija znanja i obrazovanje za održivi razvoj" (eng. "Society and Knowledge-Based Economy and Education for Sustainable Development"), published in Thematic Conference Proceedings Education and Development, (editorial board: Veselin Vukotić, Danilo Šuković, Mirjana Rašević, Slobodan Maksimović, Vladimir Goati), Institute of Social Sciences, Belgrade, (pp 69-78)

Filipović M., Đukić P., (2007) "Sustainability of Development Process in Serbia", International Conference "Contemporary of Challenges of Theory and Practice in Economics", Belgrade 26.09.07/29.09.07, Monograph: "Economic Policy and development of Serbia", Faculty of Economics, ed. Gojko Rikalović, Stevan Devetaković (p.p. 51-62)

Freedom House (2017) Nations in Transit, https://freedomhouse.org/report-types/nations-transit Huxley Aldous (2009), Vrli novi svet (eng. Brave New World), Libreto, Delf, Belgrade

Ichimura Shinichi, (2016), Japan i Azija (eng. Japan and Asia: Economic Development And Nation Building), The European Center for Peace and Development, University for Peace UN, Belgrade Jovanović-Gavrilović B., (2014), Razvoj sa ljudskim likom (eng. Development with a Human Face), Faculty of Economics, Belgrade University

Клименко Владимир Викторович (2016) Парижская конференция по климату 2015 поворотньй пункт в истории мировой энергетики, Возобновляемая энергетика ХХІ век: Энергетическая и экономическая эффективность, // Материаль Международного конгресса REENCON-XXI «Возобновляемая энергетика XXI век: Энергетическая и экономическая эфбективность». 13-14 октября 2016 г./

Kuhn, T., (1980) "Struktura naučnih revolucija" (eng. The Structure of Scientific Revolutions), Belgrade, Nolit

Marshall A., (1987) Nečela ekonomike (eng. Principles of Economics), CEKADE, Zagreb

Michael P. Todaro, C. Smith Stephen (2015) Economic Development, New York University, The George Washington, University, Pearson

Milanović Branko (2016), Globalne nejednakosti (eng. Global Inequalities), Akademska knjiga, Novi Sad

OECD (2014), National Intellectual Property, Systems, Innovation and Economic Development, With 
perspectives on ColombIa and Indonesia, (accessed on 5 May 2018)

Rischard J.F., (2008) Tačno u podne (eng. High Noon), Clio, Belgrade

W D Samuelson, P A Nordhaus, (2009), Ekonomija (eng. Economics), XVIII edition, Serbian translation MATE, Zagreb

Schwab Klaus, Sala-i-Martín Xavier - Ed. (2017) The Global Competitiveness Report 20172018, World Economic Forum http://www3.weforum.org/docs/GCR2017-2018/05FullReport/ TheGlobalCompetitivenessReport2017\%E2\%80\%932018.pdf

Sen A., (1985). O ekonomskoj nejednakosti (eng. On Economic Inequality), CEKEDE, Zagreb

Smith. A., (1970), An Inquiry into the Nature and Causes of the Wealth of Nations Kultura, Belgrade Stošić Biljana (2013), Menadžment inovacija (eng. Innovation Management), Innovation projects, models and methods, Faculty of Organisational Sciences, Belgrade University,

Vinay Lal, Ashis Nandy (2012), Budućnost znanja i culture (eng. The Future of Knowledge and Culture: A Dictionary for the 21st Century), Clio Belgrade

Marija Vugdelić - Chief Ed. (2016), Proceedings from the Scientific Conference on Climate Change, Natural Resources and Energy, Centre for Climate Change, Natural Resource and Energy, and Faculty for Food Technology, Food Science and Ecology, University of Donja Gorica, 8th of November 2016.

WEF 2016, The Global Risks Report 2016, 11th Edition. http://www3.weforum.org/docs/GRR/WEF_ GRR16.pdf

Джукич Петар, Джуканович Славиша, (2016) "РУССКО-СЕРБСКИЕ ОТНОШЕНИЯ И СТРАТЕГИИ ВО ВЗГЛЯДЕ НА УСТОЙЧИВУЮ ЭНЕРГЕТИКУ”,. КОНГРЕСС RЕЕNСОN -XХI ВОЗОБНОВЛЯЕМАЯ ЭНЕРГЕТИКА ХХІ ВЕК» 2016, стр. 10-15. Возобновляемая энергетика ХХІ век: Энергетическая и экономическая эффективность, // Материаль Международного конгресса REENCON-XXI «Возобновляемая энергетика XXI век: Энергетическая и экономическая эффективность». 13-14 октября 2016г./ Под ред.к.ф.-м.н Д.О. Дуникова, д.т.н. О.С. Попеля - Москва: ОИВТ РАН.2016. -261 с. 10-15. 